\title{
Chapter 29 \\ Towards a Near-Zero Energy Landmark \\ Building Using Building Integrated \\ Photovoltaics: The Case of the Van Unnik \\ Building at Utrecht Science Park
}

\author{
Wilfried van Sark (D) and Eelke Bontekoe $\mathbb{D}$
}

\begin{abstract}
We assess the feasibility of renovation of a 22-story high-rise building from the 1960s to realize a near-zero energy building by cladding all usable parts of facades and roof using building integrated photovoltaic (BIPV) components. With the present building electricity demand, which includes all energy demand of the building except for heating, it is not possible to generate all demand by BIPV: an annual self-sufficiency ratio of 0.666 or 0.756 is found, using two different roof designs, and $60 \%$ coverage of all facades by highly efficient (20\%) BIPV modules. Analysis of energy yield on different typical days in summer and winter reveals that the building is self-sufficient for many hours of the day. As on such days, self-consumption is relatively low, which leads to considerable feed-in of surplus electricity to the grid, application of local storage would increase self-sufficiency considerably. Furthermore, it is imperative to lower the electricity demand of the building to reach high self-sufficiency ratios.
\end{abstract}

\subsection{Introduction}

\subsubsection{Near-Zero Energy Buildings}

As buildings consume $40 \%$ of the European energy supply all new buildings in the EU built from 2020 onwards should be nearly zero energy buildings (NZEBs). This means that the energy demand of the buildings should ideally be met by local generation, at least on an annual basis. Such a building is self-sufficient [1]. The European Performance of Buildings Directive 2010/31/EU is the key market driver for this in order for the built environment to contribute to the substantial lowering of greenhouse gas emissions [2]. The 2016 "Winter Package" communicated by the European Commission stated that also existing buildings should be renovated to

W. van Sark $(\bowtie) \cdot$ E. Bontekoe

Copernicus Institute of Sustainable Development, Utrecht University, Princetonlaan 8A, 3584

Utrecht, The Netherlands

e-mail: w.g.j.h.m.vansark@uu.nl 
become NZEBs [3], and European Parliament has endorsed this. Photovoltaics will play a crucial role here: PV on roofs and façades have the potential to generate a sufficient amount of electricity to supply all necessary demand, also for heating by means of, e.g., heat pumps, if efficiency measures have been undertaken and if the building has enough surface area [4]. For example, in the Netherlands, the present average electricity consumption of a residential building is about $3500 \mathrm{kWh}$ per year, which one can generate using a $4 \mathrm{kWp} \mathrm{PV} \mathrm{system,} \mathrm{optimally} \mathrm{oriented,} \mathrm{requiring} \mathrm{about}$ $21 \mathrm{~m}^{2}$ of roof space. On an annual basis, such a household is self-sufficient.

With the expected increase in electrification of heating and transport, energy demand could easily double and a roof alone may not generate sufficient energy thus needing other surfaces for energy generation. One can imagine large solar parks around cities to provide the necessary energy, in combination with wind parks, but this may not be possible for orographic reasons and/or societal resistance. As an additional area within the city usually is limited, all roof and façade area should be investigated as to how much energy could be generated. In this respect, we have shown in a case study for the city of Utrecht that suburban areas with typical larger roof space than historical inner city neighborhoods are needed to increase the self-sufficiency of the whole city [5]. This also calls for integrated and esthetically pleasing designs of PV integrated building envelope: Building Integrated PV (BIPV) [4, 6, 7].

Optimally situated roofs lead to lowest levelized cost of electricity (LCoE) in terms of $€ / \mathrm{kWh}$ and economic payback times (PBT) of some 5-7 years, while LCoE and PBT will increase for surfaces with lower energy yield. Proper time-resolved analysis should be performed in conjunction with time-dependent demand in order to find the best options for optimization of self-consumption (direct use of PV energy) and self-sufficiency on the building level. For example, high demand at $6 \mathrm{pm}$ could be satisfied by means of a west oriented PV façade for high self-consumption.

\subsubsection{Landmark Building Renovation}

Many of the buildings at the Utrecht University campus have been built over 50 years ago, and plans are made for renovation. One of those buildings is the 22-floor "W.C. Van Unnik building" (Fig. 29.1). It is the tallest building of the campus and bears the university logo which is lit at night and can be seen from large distances. It is considered a landmark in the region. As part of the university strategy to reach an energy neutral campus in 2030, deep renovation of this landmark building to a near-zero energy building using BIPV would bring another landmark status to this building. Also, next to the already installed 1.2 MWp system, that generates $1 \mathrm{GWh}$ per year [8], or about $2 \%$ of the university's annual electricity demand [8], and that is dispersed over 8 university buildings, it is highly desirable to make PV visible to students, staff, and campus visitors.

The Van Unnik building is a 22-floor building of $76 \mathrm{~m}$ height and $57 \times 27 \mathrm{~m}^{2}$ ground floor area. The building demand at present (2017) is measured and amounts to $1.28 \mathrm{GWh}$ electricity per year, so a $1.5 \mathrm{MWp}$ optimally oriented PV system would 


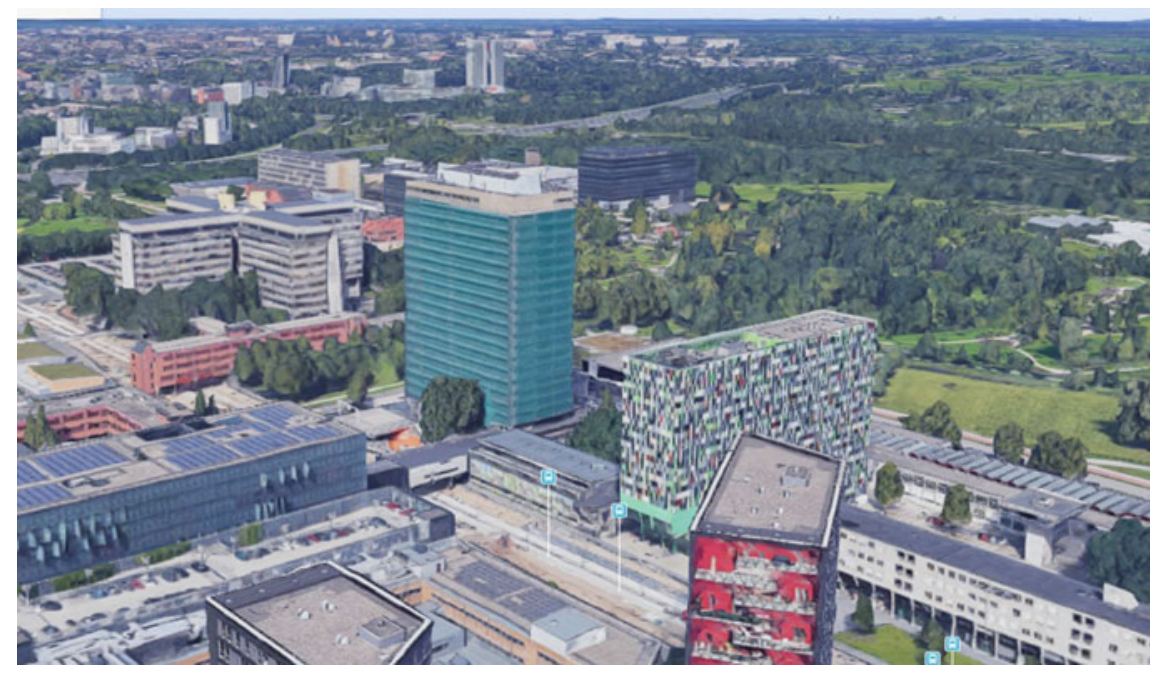

Fig. 29.1 Aerial view of the Van Unnik building from the South-East side, showing the surrounding buildings as well [9]

suffice to generate that annual demand. Electricity demand thus is $37.7 \mathrm{kWh} / \mathrm{m}^{2}$ total floor area. We note here that about half of the building was not in use due to the planned renovation so that $60-70 \mathrm{kWh} / \mathrm{m}^{2}$ would be a more realistic number. This compares well to a recent benchmark analysis of energy use in buildings in the Netherlands that reported a typical number of $50 \mathrm{kWh} / \mathrm{m}^{2}$ floor area [10]. Note, this excludes heating demand but includes the demand for cooling and ventilation.

This paper investigates in how far a BIPV design would allow the realization of a near-zero energy building. As the building is tall, large façade area would be available for BIPV.

\subsection{Calculation Methods}

\subsubsection{PV Yield}

A PV yield time series at a certain time resolution can be generated using algorithms available in the open-source Python package PV_LIB [11]. Input data such as tilt angle, azimuth angle, available area, and irradiation is required. We used global horizontal irradiation for 2013 from the Royal Netherlands Meteorological Institute (KNMI) in De Bilt, The Netherlands. Note, 2013 is chosen as annual solar irradiance is closest to the typical meteorological year [1]. The irradiation measurement interval was $10 \mathrm{~min}$. To obtain a 5-min data set linear interpolation was done. Global tilted orientation was calculated using the transposition algorithms in PV_LIB. To illustrate 
seasonal effects, we will show typical summer and winter day data for clear sky, completely overcast, and mixed clear/cloudy conditions. To calculate PV energy yield, we used a single PV module efficiency of $20 \%$, corresponding to using 320 $\mathrm{Wp}$ modules of $1.6 \mathrm{~m}^{2}$ size, and multiplied this with a performance ratio $(\mathrm{PR})$ value of 0.85 to account for temperature and other system losses, which is consistent with well-performing PV systems in the Netherlands [12]. The actual design of a PV system covering façades and roof of a building is facilitated by the availability of 3D drawings of buildings, such as in SketchUp [13]. The design tool developed in the PVSITES project [14] then allows to calculate solar irradiation on all surfaces. We have used this in designing the PV cladding.

The Van Unnik building is a 22-floor building of $76 \mathrm{~m}$ height and $57 \times 27 \mathrm{~m}^{2}$ ground floor area. It is oriented such that is has a large South and North façade, both having an area of $4332 \mathrm{~m}^{2}$, and a considerably smaller East and West façade of $2052 \mathrm{~m}^{2}$. For every floor, the windows are 1.4 in height, while individual floor height is 3.45 . Hence, $60 \%$ of the façade is usable for PV modules, excluding windows. The roof area is $1539 \mathrm{~m}^{2}$. The PV energy yield is calculated for $\mathrm{N}, \mathrm{S}, \mathrm{E}$, and $\mathrm{W}$ orientations each at $90^{\circ}$ tilt. For the roof, we use two options, either south facing modules at optimum $37^{\circ}$ tilt, with proper interrow distance, i.e., a usable fraction of $50 \%$, or a combination of east and west facing modules at $10^{\circ}$ tilt.

\subsubsection{Self-sufficiency and Self-consumption}

The self-consumption ratio $S C R$ is defined as the amount of PV energy $E_{P V \text {,cons }}$ that are directly consumed divided by the total amount of PV energy generated $E_{P V \text {,tot }}$ :

$$
S C R=\frac{E_{P V, \text { cons }}}{E_{P V, t o t}}
$$

The self-sufficiency ratio is $S S R$ defined as the amount of PV energy $E_{P V \text {,cons }}$ that are directly consumed divided by the electricity demand of a building $E_{c o n s}$ :

$$
S S R=\frac{E_{P V, \text { cons }}}{E_{\text {cons }}}
$$

In order to calculate self-sufficiency and self-consumption, electricity demand data at 15-min time resolution was collected using certified $\mathrm{kWh}$ meters for the Van Unnik building. Also here, linear interpolation was performed to achieve a 5-min time resolution.

SCR and SSR can be defined for any time interval. In this paper, we use annual and (some) daily ratios. 


\subsection{Results}

\subsubsection{PV System Design, Annual Data Analysis}

We used PVSITES to make a PV system design based on the assumption to fully cover the usable façade area (60\% of total façade) and the roof of the building with PV modules tilted south, see for details Fig. 29.2. We have used the Sunpower SPR320EWHTD module for this, from the database of modules available in PVSites. The dimensions of the building allow to install two rows of 34 modules each in landscape orientation per floor on the south and north facades, and rows of 12 modules on the east and west facades. These are then connected per level to 40 inverters of different capacity and with double MPPT trackers (ABB Trio-7.5-TL-OUTD (east and west) and TRIO-27.6-TL-OUTD (north and south)). For roof and other parts, 28 additional inverters are used.

We find that a total PV capacity of $1.69 \mathrm{MWp}$ is possible, which is calculated to generate $853.1 \mathrm{MWh}$ of solar energy per year. The annual self-sufficiency ratio thus is 0.666 . Covering the roof instead with a combination of east and west oriented modules at $10^{\circ}$ tilt allows to install $1.84 \mathrm{MWp}$, which generates $968.0 \mathrm{MWh}$ annually, and self-sufficiency ratio is 0.756 . To reach a self-sufficiency ratio equaling one, electricity demand must reduce to about $25 \mathrm{kWh} / \mathrm{m}^{2}$.

The specific yields are $505.9 \mathrm{kWh} / \mathrm{kWp}$ and $526.1 \mathrm{kWh} / \mathrm{kWp}$, respectively. A breakdown of these results is shown in Table 29.1. Obviously, the south facing facade shows the largest PV capacity and energy yield, due to its large area, while the specific yield is considerably lower $(\sim 60 \%)$ than the one for an optimally tilted

(a)

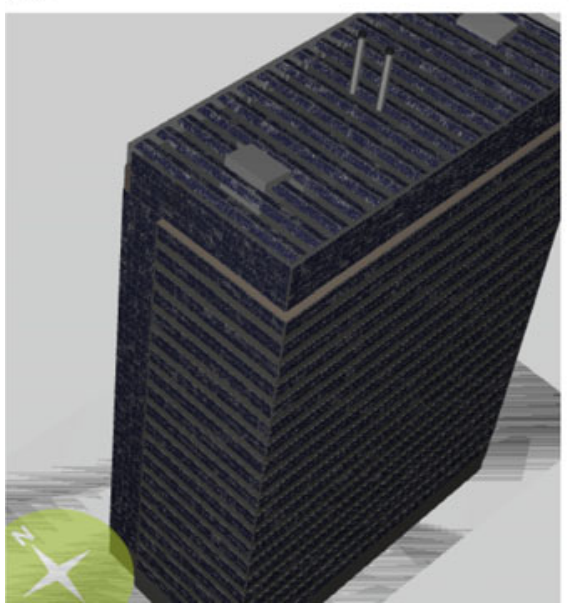

(b)

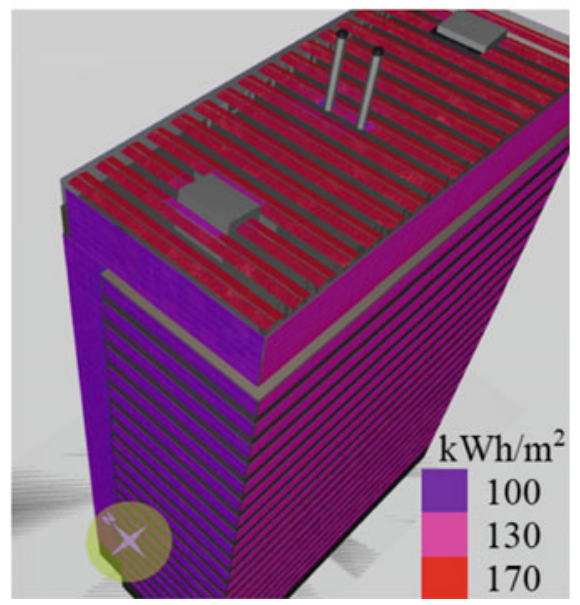

Fig. 29.2 Design of the PV system for the Van Unnik building, using PVSITES [14]. a Aerial view from the south-east, $\mathbf{b}$ color coded energy generation view 
Table 29.1 Calculated PV capacity, annual yield and specific yield, for the façades and roof

\begin{tabular}{l|l|l|l|l}
\hline Surface & $\begin{array}{l}\text { PV capacity } \\
(\mathrm{kWp})\end{array}$ & $\begin{array}{l}\text { Annual energy } \\
\text { yield }(\mathrm{MWh})\end{array}$ & $\begin{array}{l}\text { Specific yield } \\
(\mathrm{kWh} / \mathrm{kWp})\end{array}$ & $\begin{array}{l}\text { Yield per unit } \\
\text { area }\left(\mathrm{kWh} / \mathrm{m}^{2}\right)\end{array}$ \\
\hline South facade & 519.8 & 311.1 & 598.5 & 71.18 \\
\hline North facade & 519.8 & 151.9 & 292.2 & 35.06 \\
\hline East facade & 246.2 & 112.9 & 458.4 & 55.02 \\
\hline West facade & 246.2 & 125.1 & 507.9 & 60.96 \\
\hline Roof (South tilt) & 153.9 & 152.1 & 988.6 & 98.83 \\
\hline Roof (East tilt) & 153.9 & 132.9 & 863.5 & 86.35 \\
\hline Roof (West tilt) & 153.9 & 134.2 & 872.1 & 87.20 \\
\hline
\end{tabular}

system-oriented south. A recent detailed study on vertical solar irradiance in Spain shows similar numbers [15]. Although we do not focus on cost-effectiveness here, a combination of systems with high specific yield would be economically of most interest, i.e. a south facade combined with a combined east/west oriented roof system.

Placing PV on the North façade seems not to be an economical solution because of its low specific yield. Alternatively, using the roof of the neighboring Educatorium building (to the North) would be much more cost-effective. Nevertheless, using the North façade has other advantages, such as a higher self-consumption and the visibility of PV. Further on, with declining PV costs and growing demand for renewable energy even using the North façade could soon become economically viable.

\subsubsection{Daily Data Analysis}

Figure 29.3a shows the daily solar irradiation variation for three days in summer and three days in winter, i.e., a sunny day, a completely overcast day and a mixed cloudy day. Figure 29.3b shows the building energy demand for the building for those days. A clear baseload during the night can be observed of about 100-120 kW irrespective of the season, which can be attributed to air circulation equipment. During daytime, demand increases to $220-280 \mathrm{~kW}$, with higher demands in winter, most probably due to higher lighting demands. The heating itself is not included.

For these six days, we have calculated the amount of solar energy harvested for all facades separately as well as for the two roof options, see Fig. 29.4, and 29.5 for self-consumption and self-sufficiency ratios. We also compare the actual energy demand with the net demand in case the energy generated from the facade and the optimally tilted south facing roof PV system would be used directly in the building, i.e., self-consumed. We note that figures for energy from the facades and the east/west roof system combination are somewhat higher (not shown here). It can be clearly observed that in summer the net demand is negative for the clear and cloudy day, and surplus electricity is fed back into the campus grid, see also Table 29.2. Although for the clear winter day self-consumption is high and surplus electricity is fed back 
(a)

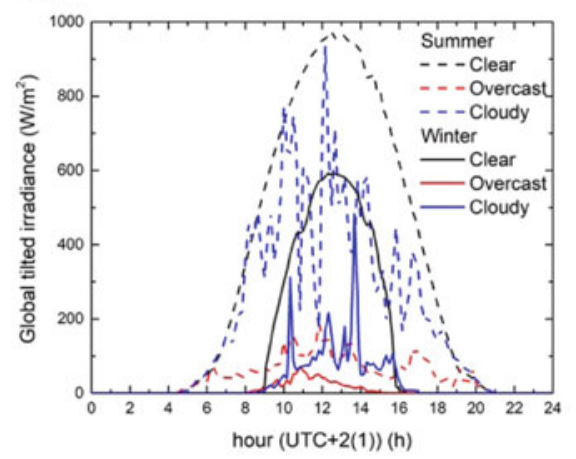

(b)

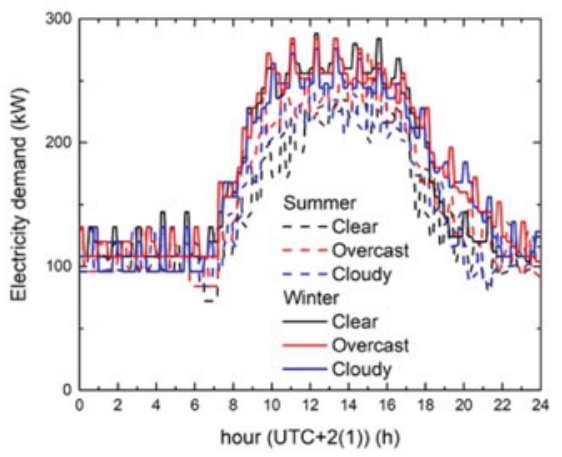

Fig. 29.3 a Solar irradiance for six days in 2017, three in summer and three in winter, for clear, overcast and mixed cloudy conditions, for a south facing system at an optimum tilt. b Building electricity demand for the same days. Time step is $5 \mathrm{~min}$

(a)

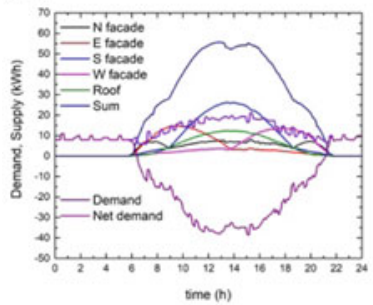

(d)

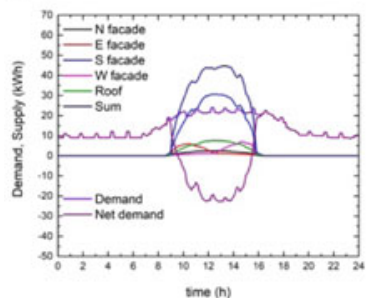

(b)

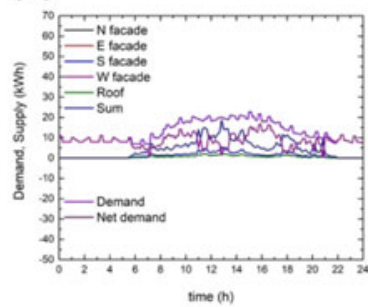

(e)

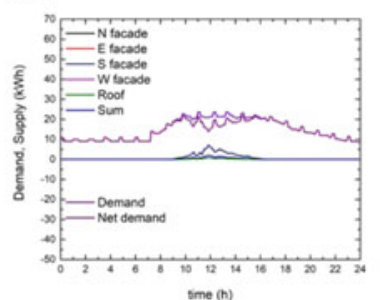

(c)

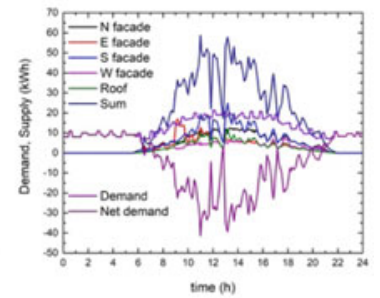

(f)

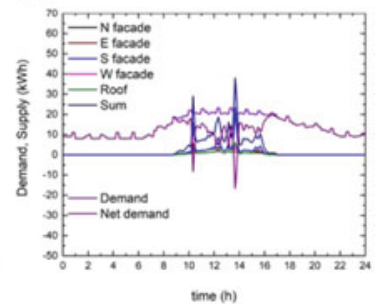

Fig. 29.4 PV energy from façades and roof using solar irradiance for six days in 2017 (Fig. 29.2), and electricity demand with (net) and without PV. Three days in summer $(\mathbf{a}, \mathbf{b}, \mathbf{c})$ and three in winter, for clear $(\mathbf{a}, \mathbf{d})$, overcast $(\mathbf{b}, \mathbf{e})$ and mixed cloudy $(\mathbf{c}, \mathbf{f})$ conditions. Time step is $5 \mathrm{~min}$ 
(a)

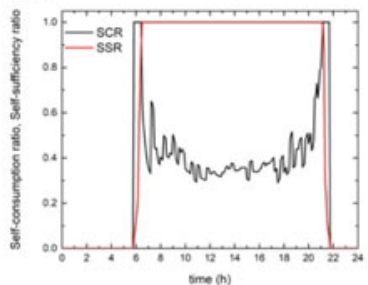

(d)

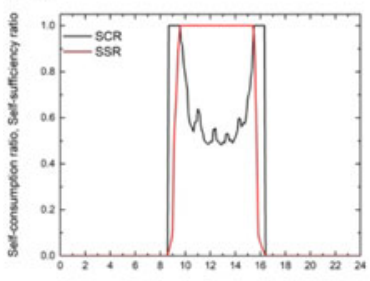

time (n) (b)

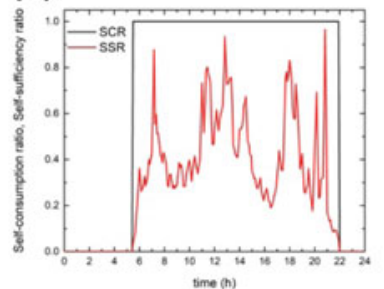

(e)

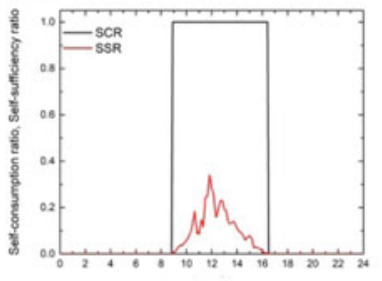

bime (h) (c)

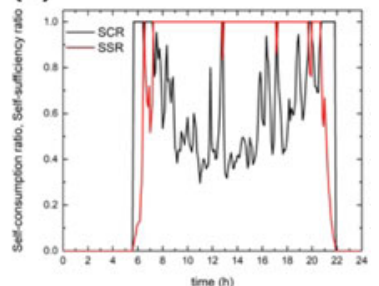

(f)

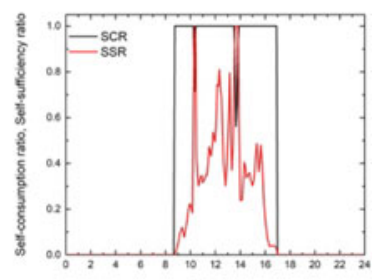

time (h)

Fig. 29.5 Self-consumption (black solid line) and self-sufficiency (red solid line) ratios for the Van Unnik building, using data in Fig. 29.4, for three days in summer (a, b, c) and three in winter, for clear $(\mathbf{a}, \mathbf{d})$, overcast $(\mathbf{b}, \mathbf{e})$ and mixed cloudy $(\mathbf{c}, \mathbf{f})$ conditions. We only show results for the case that energy is generated from all facades and the optimally tilted south facing roof PV system. Time step is $5 \mathrm{~min}$

Table 29.2 Electricity demand, self-consumption, electricity fed back to the grid, and cumulative net demand for six typical days, for the case that energy is generated from all facades and the optimally tilted south facing roof PV system

\begin{tabular}{l|l|l|c|c}
\hline Days & Demand $(\mathrm{kWh})$ & $\begin{array}{l}\text { Self-consumption } \\
(\mathrm{kWh})\end{array}$ & To grid $(\mathrm{kWh})$ & $\begin{array}{l}\text { Net demand } \\
(\mathrm{kWh})\end{array}$ \\
\hline Summer, clear & 3474 & 2566 & 4209 & -3301 \\
\hline Summer, overcast & 3804 & 1310 & 0 & 2493 \\
\hline Summer, cloudy & 3662 & 2632 & 2404 & -1374 \\
\hline Winter, clear & 4200 & 1708 & 1159 & 1333 \\
\hline Winter, overcast & 4300 & 215 & 0 & 4084 \\
\hline Winter, cloudy & 4140 & 755 & 40 & 3345 \\
\hline
\end{tabular}

into the grid, the net demand is still positive. Even if the net demand is negative, the self-sufficiency ratio does not equal unity, as can be seen in Table 29.3.

The self-consumption and self-sufficiency ratios are shown in Fig. 29.5, which corroborate the findings from Fig. 29.4 in that self-sufficiency equals unity for the moments at which surplus electricity is fed back into the grid. Also, at those times, only a fraction of the PV generated energy is directly self-consumed. On a daily basis, the self-sufficiency ratio is lower to one, obviously due to nighttime demand. As the net demand is negative, surplus electricity could be locally stored in stationary 
Table 29.3 Calculated SCR and SSR for six typical days and two options for the PV system

\begin{tabular}{l|l|l|l|l}
\hline Days & \multicolumn{2}{l|}{ Facades and Roof South } & \multicolumn{2}{l}{ Facades and Roof East/West } \\
\hline & SCR & SSR & SCR & SSR \\
\hline Summer, clear & 0.379 & 0.739 & 0.326 & 0.740 \\
\hline Summer, overcast & 1.000 & 0.344 & 0.998 & 0.395 \\
\hline Summer, cloudy & 0.523 & 0.719 & 0.456 & 0.725 \\
\hline Winter, clear & 0.573 & 0.407 & 0.593 & 0.406 \\
\hline Winter, overcast & 1.000 & 0.051 & 1.000 & 0.058 \\
\hline Winter, cloudy & 0.950 & 0.182 & 0.952 & 0.202 \\
\hline
\end{tabular}

battery systems and used later. In that case, the self-sufficiency ratio can equal unity, while still surplus electricity is generated.

\subsubsection{Discussion}

The results show that the annual cumulative electricity demand is higher than can be generated by PV systems in the configurations used. While the generation capacity of the combined facade and roof system is high, the electricity demand is simply too high. To reach a near-zero energy building, considering only electricity demand, efficiency measures have to be taken such that electricity demand is lowered to about $25 \mathrm{kWh} / \mathrm{m}^{2}$, on annual basis. On a daily basis, electricity import or export will occur, depending on solar irradiance variations.

The suggested design may not be valued in terms of esthetics, while we also do not consider the effect of nearby buildings. This will lead to lower energy yields, which stresses the importance of realizing even lower electricity demands than 25 $\mathrm{kWh} / \mathrm{m}^{2}$, perhaps even ambitiously as low as $10 \mathrm{kWh} / \mathrm{m}^{2}$.

\subsection{Conclusion}

We have presented a BIPV design that can be used in the renovation of the landmark Van Unnik building with the purpose of realizing a net-zero energy building. Given the present electricity demand of $37.7 \mathrm{kWh} / \mathrm{m}^{2}$ total floor area where half of the building is utilized, the building cannot be made self-sufficient. An annual selfsufficiency ratio of 0.666 or 0.756 is found, using two different roof designs, while covering $60 \%$ of all facades by BIPV modules. Daily self-sufficiency ratios can be unity for sunny days if surplus electricity can be stored locally in batteries. Annual self-sufficiency ratio of unity can be reached if the electricity demand is lowered to about $25 \mathrm{kWh} / \mathrm{m}^{2}$ total floor area. 
Acknowledgements We would like to thank Frans Tak (UU) for supplying energy demand data, Geert Litjens (UU) for having developed PV_LIB based python codes, the PVSITES project coordinator (Maider Machado) for using their 3D simulation tool prior to public release, and the DEM4BIPV project partners for many stimulating discussions. This work is supported by the "Werkelijk Bouwen aan BIPV" project, which is funded by the European Innovation program for the South of the Netherlands (OPZuid), as part of the European Fund for Regional Development (EFRO) of the European Union, as well as by the KA2 Strategic Partnerships for the higher education program of Erasmus+ under contract 2015-1-NL01-KA203-008882.

\section{References}

1. Litjens, G.B.M.A., Worrell, E., van Sark, W.G.J.H.M.: Influence of demand patterns on the optimal orientation of photovoltaic systems. Sol. Energy 155, 1001-1014 (2017)

2. European Commission Directive 2010/31/EU of the European Parliament and of the Council of 19 May 2010 on the energy performance of buildings. Off. J. Eur. Union L 153, 13-35 (2010)

3. European Commission Proposal for a Directive of the European Parliament and of the Council amending Directive 2010/31/EU on the energy performance of buildings. http://eur-lex.europa. eu/legal-content/EN/TXT/?uri=CELEX:52016PC0765

4. Scognamiglio, A., Røstvik, H.N.: Photovoltaics and zero energy buildings: a new opportunity and challenge for design. Prog. Photovolt. Res. Appl. 21, 1319-1336 (2013)

5. Litjens, G.B.M.A., Kausika, B.B., Worrell, E., van Sark, W.G.J.H.M.: A spatio-temporal cityscale assessment of residential photovoltaic power integration scenarios. Sol. Energy 174, 1185-1197 (2018)

6. Heinstein, P., Ballif, C., Perret-Aebi, L.-E.: Building integrated photovoltaics (BIPV): review, potentials. Barriers Myths. Green 3, 125-156 (2013)

7. Tripathy, M., Sadhu, P.K., Panda, S.K.: A critical review on building integrated photovoltaic products and their applications. Renew. Sustain. Energy Rev. 61, 451-465 (2016)

8. van Sark, W., de Waal, A., Uithol, J., Dols, N., Houben, F., Kuepers, R., Scherrenburg, M., van Lith, B., Benjamin, F.: Energy performance of a 1.2 MWp photovoltaic system distributed over eight buildings at Utrecht University Campus. In: Proceedings of the 33rd European Photovoltaic Solar Energy Conference and Exhibition, pp. 2284-2287 (2017)

9. Google maps. https://goo.gl/maps/xsCv5q3iJEoeYR8A9. Accessed 10 March 2019

10. Sipma, J.M.: Nieuwe benchmark energieverbruik utiliteitsgebouwen en industriële sectoren. Petten, The Netherlands (2016)

11. Andrews, R.W., Stein, J.S., Hansen, C., Riley, D.: Introduction to the open source PV_LIB for python photovoltaic system modelling package. In: Proceedings of the IEEE 40th Photovoltaic Specialist Conference (PVSC), pp. 170-174 (2014)

12. Kausika, B.B., Moraitis, P., Van Sark, W.: Visualization of operational performance of gridconnected PV systems in selected european countries. Energies 11, 1330 (2018)

13. Sketchup. www.sketchup.com. Accessed 17 Feb 2018

14. Machado, M., Challet, S., Weiss, I., Román Medina, E., Espeche, J.M., Noris, F., Reijenga, T., Rico, E., Huerta, I., Assoa, Y.B., et al.: Supporting market uptake of building-integrated photovoltaic technologies with the PVSITES project. In: Proceedings of the 33rd European Photovoltaic Solar Energy Conference and Exhibition, pp. 2882-2887 (2017)

15. Díez-Mediavila, M., Rodríguez-Amigo, M.C., Dieste-Velasco, M.I., García-Calderón, T., Alonso-Tristán, C.: The PV potential of vertical façades: A classic approach using experimental data from Burgos. Spain. Sol. Energy 177, 192-199 (2019) 